\title{
The Effect of Olive Oil Addition into Oatmeal in Lowering Total Blood Cholesterol and LDL (Low Density Lipoprotein) in Wistar Rat
}

\author{
Sebastian Hadinata*, Heddy Herdiman**, Fenny**** \\ * Faculty of Medicine Maranatha Christian University \\ **Department of Anatomy Faculty of Medicine Maranatha Christian University \\ *** Department of Clinical Pathology \\ Faculty of Medicine Maranatha Christian University \\ Jl. Prof. drg. Suria Sumantri MPH No. 65 Bandung 40164 Indonesia \\ Email : sebastianhadinata5@gmail.com
}

\begin{abstract}
Oat contains beta-glucan fiber and olive oil contains unsaturated fatty acids which have been proven to decrease blood cholesterol. This research compared the effect between a combination of oatmeal and olive oil and each food as single intake in decreasing total blood cholesterol and LDL cholesterol. We used 25 rats (Rattus norvegicus L.), divided them into five groups; negative control $(K N)$, positive control $(K P)$, olive oil group (KMZ), oatmeal group $(K B G)$, and combination group $(K M Z+K B G)$. The total blood cholesterol and LDL cholesterol levels were measured after 14 days of induction and after 28 days of treatment. Data were analyzed using one way ANOVA, continued with LSD test with $\alpha=0.05$. The result showed there were $10.85 \%, 8.85 \%$ and $6.60 \%$ lower in total blood cholesterol level using $K M Z+K B G$, $K M Z$ and $K B G$ respectively and 13.85\%, 9.33\% , and 8.80\% lower in LDL cholesterol level using $K M Z+K B G, K M Z$ and $K B G$ respectively. ANOVA test showed a significant decrease in each treatment. $L S D$ test showed that there was a significant difference between $K M Z+K B G$ compared to KBG in total blood cholesterol and LDL lowering, but did not showed significant difference compared to $K M Z$.
\end{abstract}

Keywords: oatmeal, olive oil, total blood cholesterol, $L D L$ 


\title{
Pengaruh Penambahan Minyak Zaitun Pada Bubur Gandum Terhadap Perubahan Kolesterol Total dan LDL (Low Density Lipoprotein) pada Tikus Galur Wistar
}

\author{
Sebastian Hadinata*, Heddy Herdiman**, Fenny**** \\ * Fakultas Kedokteran Universitas Kristen Maranatha \\ **Bagian Anatomi Fakultas Kedokteran Universitas Kristen Maranatha \\ ***Bagian Patologi Klinik Fakultas Kedokteran Universitas Kristen Maranatha \\ Jl. Prof. drg. Suria Sumantri MPH No. 65 Bandung 40164 Indonesia \\ Email : sebastianhadinata5@gmail.com
}

\begin{abstract}
Abstrak
Gandum mengandung serat beta-glucan dan minyak zaitun mengandung asam lemak yang telah diketahui dapat menurunkan kadar kolesterol total dan LDL. Penelitian ini membandingkan efek pemberian kombinasi dari bubur gandum dan minyak zaitun atau pemberian tunggal dari masing-masing bahan makanan terhadap penurunan kadar kolesterol total dan kolesterol LDL. Penelitian ini menggunakan desain eksperimental sungguhan dengan Rancangan Acak Lengkap (RAL), menggunakan 25 hewan coba tikus (Rattus norvegicus L.) yang dibagi menjadi 5 kelompok perlakuan yaitu kontrol negatif (KN), kontrol positif (KP), kelompok minyak zaitun (KMZ), kelompok bubur gandum (KBG) dan kelompok gabungan (KMZ+KBG). Kolesterol total dan kolesterol LDL diukur setelah induksi 14 hari dan setelah perlakuan selama 28 hari. Analisis data menggunakan uji Analisis Varian satu arah ,dilanjutkan dengan uji LSD dengan $\alpha=0,05$. Pada penelitian ini didapatkan penurunan kadar kolesterol total sebesar $10,85 \%$ pada $\mathrm{KMZ}+\mathrm{KBG}, 8,85 \%$ pada $\mathrm{KMZ}$ dan $6,60 \%$ pada $\mathrm{KBG}$ dan LDL $13,85 \%$ pada KMZ+KBG, 9,33\% pada KMZ dan pada 8,80\% KBG. Statistik ANAVA menunjukkan penurunan yang bermakna dari masing-masing perlakuan. Uji LSD menunjukkan perbedaan yang bermakna antara $\mathrm{KMZ}+\mathrm{KBG}$ bila dibandingkan dengan KBG terhadap penurunan kadar kolesterol total dan LDL, namun tidak berbeda bermakna bila dibandingkan dengan KMZ.
\end{abstract}

Kata kunci: bubur gandum, minyak zaitun, kolesterol total, LDL 


\section{Research Article}

\section{Pendahuluan}

Dislipidemia adalah suatu kelainan kadar lipoprotein darah baik berupa peningkatan fraksi lipid seperti kolesterol LDL, trigliserida, kolesterol total, penurunan kolesterol HDL atau kombinasi diantaranya. ${ }^{1}$ Frederickson dan Levy mengklasifikasikan dislipidemia kedalam enam golongan yaitu golongan I, IIa, IIb, III, IV, dan V. Diantara keenam tipe dislipidemia ini, golongan IIa merupakan yang paling sering. Dislipidemia tipe IIa ini ditandai dengan peningkatan kadar kolesterol total, LDL, penurunan kadar HDL dan peningkatan risiko terjadinya penyakit kardiovaskular. ${ }^{2}$

Dislipidemia, terutama hiperkolesterolemia familial telah menjadi masalah kesehatan masyarakat yang sering ditemukan. Insidensi dari kasus ini adalah 1/500 orang. ${ }^{2}$ Hal ini selain berhubungan erat dengan faktor genetik juga sangat dipengaruhi dengan faktor gaya hidup. Di Indonesia dan secara umum di dunia insidensi dislipidemia meningkat dari tahun ke tahun dan uniknya berbanding lurus dengan peningkatan taraf ekonomi yang ditandai dengan meningkatnya jumlah warga kelas menengah ke atas. ${ }^{3}$ Peningkatan taraf ekonomi ini menyebabkan perubahan gaya hidup yang semakin kearah sedentary lifestyle (gaya hidup dengan aktivitas fisik yang minim atau tidak teratur). ${ }^{4}$

Peningkatan taraf hidup ini juga menyebabkan daya beli masyarakat yang semakin meningkat. ${ }^{5}$ Hal ini dapat memberikan dampak positif yaitu semakin mudahnya mencari informasi tentang kesehatan dari berbagai sumber media informasi. ${ }^{6}$

Bahan makanan seperti gandum yang mengandung serat beta-glucan ${ }^{7}$ dan minyak zaitun yang mengandung asam lemak tidak jenuh ${ }^{8}$ telah diteliti dapat menurunkan kadar kolesterol darah. Seperti yang telah disebutkan sebelumnya, peningkatan taraf hidup yang berdampak pada peningkatan pengetahuan masyarakat mengenai kesehatan diharapkan dapat meningkatkan konsumsi masyarakat akan kedua bahan makanan ini.

\section{Metode}

Duapuluh lima ekor tikus diinduksi dengan menggunakan pakan tinggi lemak yang diberikan sebanyak 25 gram / ekor tikus / hari, Propiltiouracil 0,01\% di dalam air minum, dan fruktosa 60\% selama 14 hari. Profil lipid kolesterol total dan kolesterol LDL tikus selanjutnya diperiksa dari serum yang diambil melalui pungsi vena ekor tikus untuk memastikan tikus sudah mengalami dislipidemia.

Hewan coba selanjutnya dikelompokan dan diberikan perlakuan sebagai berikut :

- Variabel kontrol negatif : kelompok ini hanya diberhentikan dari diet tinggi lemak 
- Variabel kontrol positif: kelompok ini diberikan pakan modifikasi pelet dan simvastatin $0,36 \mathrm{mg}$ selama 28 hari

- Variabel 1: kelompok ini diberikan pakan modifikasi pelet dan bubur gandum 1,8 g selama 28 hari

- Variabel 2: kelompok ini diberikan pakan modifikasi pelet dan minyak zaitun 0,45 ml selama 28 hari

- Variabel 3: kelompok ini diberikan pakan kombinasi pelet dan kombinasi minyak zaitun $0,45 \mathrm{ml}$ dan bubur gandum $1,8 \mathrm{~g}$ selama 28 hari

Profil lipid dari 25 tikus diperiksa ulang melalui pungsi vena ekor. Analisis data menggunakan metode ANAVA satu arah dengan $\alpha=0,05$. F hitung akan dibandingkan dengan $\mathrm{F}$ tabel. Bila F hitung $\geq \mathrm{F}$ tabel, maka perbedaan disebut signifikan. Jika didapat hasil signifikan (minimal ada sepasang perlakuan yang berbeda), maka dilanjutkan dengan LSD. Dengan menggunakan LSD (Least Significant Difference), hasil akan dibandingkan dengan tabel LSD $5 \%$. Bila selisih absolut antara dua macam perlakuan $\geq$ tabel LSD 5\%, maka disebut signifikan. Bila selisih absolut antara dua macam perlakuan $<$ tabel LSD 5\%, maka disebut nonsignifikan.

\section{Hasil}

Tabel 1 Rerata Persentase Penurunan Kadar Kolesterol Total Serum Tikus Setelah Induksi dan Setelah Perlakuan

\begin{tabular}{cccc}
\hline Kelompok & $\begin{array}{c}\text { Setelah } \\
\text { Induksi }\end{array}$ & $\begin{array}{c}\text { Setelah } \\
\text { Perlakuan }\end{array}$ & $\begin{array}{c}\text { Rerata Persentase } \\
(\%)\end{array}$ \\
\hline KN & 165 & 154,2 & $6,55 \%$ \\
KP & 167 & 137,6 & $17,60 \%$ \\
KMZ & 160,4 & 146,2 & $8,85 \%$ \\
KBG & 166,6 & 155,6 & $6,60 \%$ \\
KMZ+KBG & 164 & 146,2 & $10,85 \%$ \\
\hline
\end{tabular}

Keterangan:

$\mathrm{KN} \rightarrow$ kontrol negatif; KP $\rightarrow$ kontrol positif diberikan simvastatin $0,36 \mathrm{mg}$; KMZ $\rightarrow$ kelompok minyak zaitun diberikan minyak zaitun $0,45 \mathrm{ml}$; KBG $\rightarrow$ kelompok bubur gandum diberikan bubur gandum 1,8 g; KBG + KMZ $\rightarrow$ kelompok kombinasi yang diberikan minyak zaitun $0,45 \mathrm{ml}$ dan bubur gandum $1,8 \mathrm{~g}$.

Dari hasil penghitungan statistik ANAVA satu arah didapatkan bahwa penurunan kolesterol total serum tikus setelah perlakuan memberikan hasil yang sangat signifikan dengan $F_{\text {hitung }} 7,457$ lebih besar dari $F_{\text {tabel }} 0,01$ sebesar 4,43. Selanjutnya dilakukan uji LSD dengan $\alpha=$ 0,05 dan dengan kemaknaan $\mathrm{p}<0,05$. Hasil dari uji LSD disajikan dalam tabel 2. 
Tabel 2 Uji LSD Penurunan Kolesterol Total Serum Tikus terhadap Masing-masing Perlakuan

\begin{tabular}{l|ccccc}
\hline \multicolumn{1}{c}{ Kelompok } & KN & KP & KMZ & KBG & KMZ+KBG \\
\hline KN & & $*$ & $*$ & - & $*$ \\
KP & & & - & - & - \\
KMZ & & & & - & - \\
KBG & & & & $*$ \\
KMZ+KBG & & & & \\
\multicolumn{2}{l}{ Keterangan: } \\
$(*) \rightarrow$ menunjukkan perbedaan yang bermakna; $(-) \rightarrow$ tidak menunjukkan perbedaan yang bermakna
\end{tabular}

Tabel 3 Rerata Persentase Penurunan Kadar Kolesterol LDL Serum Tikus Setelah Induksi dan Setelah Perlakuan

\begin{tabular}{cccc}
\hline Kelompok & $\begin{array}{c}\text { Setelah } \\
\text { Induksi }\end{array}$ & $\begin{array}{c}\text { Setelah } \\
\text { Perlakuan }\end{array}$ & $\begin{array}{c}\text { Rerata Persentase } \\
(\%)\end{array}$ \\
\hline KN & 124,6 & 116,4 & $6,58 \%$ \\
KP & 119 & 101,2 & $14,96 \%$ \\
KMZ & 115,8 & 105 & $9,33 \%$ \\
KBG & 118,2 & 107,8 & $8,80 \%$ \\
KMZ+KBG & 118,4 & 102 & $13,85 \%$ \\
\hline
\end{tabular}

Dari hasil penghitungan statistik ANAVA satu arah didapatkan bahwa penurunan kolesterol LDL serum tikus setelah perlakuan memberikan hasil yang sangat signifikan dengan $\mathrm{F}_{\text {hitung }} 11,427$ lebih besar dari $\mathrm{F}_{\text {tabel }} 0,01$ sebesar 4,43. Selanjutnya dilakukan uji LSD dengan $\alpha=$ 0,05 dan dengan kemaknaan $\mathrm{p}<0,05$. Hasil dari uji LSD disajikan dalam tabel 4. 


\section{Tabel 4 Uji LSD Penurunan Kolesterol LDL Serum Tikus terhadap Masing-masing Perlakuan}

\begin{tabular}{lccccc}
\hline \multicolumn{1}{c}{ Kelompok } & KN & KP & KMZ & KBG & KMZ+KBG \\
\hline KN & & $*$ & $*$ & $*$ & $*$ \\
$\mathbf{K P}$ & & & - & - & - \\
$\mathbf{K M Z}$ & & & - & - \\
$\mathbf{K B G}$ & & & & $*$ \\
$\mathbf{K M Z + K B G}$ & & & & \\
\multicolumn{2}{c}{ Keterangan: } \\
$(*) \rightarrow$ menunjukkan perbedaan yang bermakna; (-) $\rightarrow$ tidak menunjukkan perbedaan yang bermakna
\end{tabular}

Berdasarkan statistik ANAVA satu arah didapatkan bahwa penurunan kolesterol total dan kolesterol LDL serum tikus setelah perlakuan memberikan hasil yang sangat signifikan. Uji LSD dengan $\alpha=0,05$ dan kemaknaan $\mathrm{p}<0,05$ pada masing-masing penurunan kadar kolesterol total serum tikus tiap perlakuan didapatkan bahwa kontrol positif, kelompok minyak zaitun dan kelompok gabungan mengalami penurunan kadar kolesterol total yang signifikan dibandingkan dengan kontrol negatif.

\section{Diskusi}

Penurunan kadar kolesterol total pada pemberian bubur gandum saja tidak berbeda bermakna bila dibandingkan dengan kontrol negatif. Pemberian bubur gandum saja hanya memberikan efek terhadap ekskresi kolesterol. Zat beta glucan gandum mengikat asam empedu di saluran pencernaan sehingga kolesterol tidak dapat diserap kembali oleh ileum. ${ }^{9}$ Gangguan pada siklus enterohepatik asam empedu ini dapat menurunkan kadar kolesterol plasma sekitar $10 \%$ sebelum suatu equilibrium baru terbentuk. ${ }^{2}$ Pada penelitian ini didapatkan penurunan kadar kolesterol total sebesar $6,60 \%$ setelah pemberian bubur gandum selama 28 hari. Setelah dilakukan uji statistik LSD dengan $\alpha=0,05$ dan kemaknaan $\mathrm{p}<0,05$ didapatkan bahwa pemberian bubur gandum ini tidak menimbulkan perbedaan yang bermakna dibandingkan dengan kontrol negatif.

Penurunan kadar kolesterol total dengan pemberian gabungan minyak zaitun dan bubur gandum memberikan hasil yang tidak berbeda bermakna dibandingkan dengan pemberian minyak zaitun saja. Hal ini menunjukkan minyak zaitun sudah dapat memberikan efek yang baik di dalam penurunan kadar kolesterol total serum. Hal ini diduga minyak zaitun sudah memiliki mekanisme ganda terhadap penurunan kadar kolesterol serum yang mana minyak 


\section{Research Article}

zaitun meningkatkan sekresi dan ekskresi dari empedu melalui aksi koleretik dan kolesistokinetik sehingga berefek secara tidak langsung pada eskresi kolesterol melalui empedu. ${ }^{8}$ Menurut penelitian lain yang dilakukan terhadap tikus senyawa polifenol ${ }^{11,12}$ pada minyak zaitun dapat menurunkan aktivitas enzim HMG-KoA reduktase pada mikrosom hepar. ${ }^{10}$

Uji LSD dengan $\alpha=0,05$ dan kemaknaan $\mathrm{p}<0,05$ pada masing-masing penurunan kadar kolesterol LDL serum tikus tiap perlakuan didapatkan bahwa kontrol positif, kelompok minyak zaitun, kelompok bubur gandum dan kelompok gabungan mengalami penurunan kadar kolesterol LDL yang signifikan dibandingkan dengan kontrol negatif. Berdasarkan statistik, pemberian kombinasi menunjukkan hasil yang lebih baik dari pemberian bubur gandum saja, namun tidak menunjukkan perbedaan yang bermakna bila dibandingkan dengan pemberian minyak zaitun saja. Bila dilihat dari kekuatan penurunan kadar kolesterol LDL, kelompok kombinasi menunjukkan penurunan yang lebih besar dari pemberian minyak zaitun saja. Penulis menduga adanya efek sinergisme antara bubur gandum dan minyak zaitun. Adapun hipotesis mekanisme yang terjadi adalah adanya sinergisme yang memperkuat ekskresi asam empedu dan gangguan terhadap siklus enterohepatik yang ditimbulkan antara zat lipid minyak zaitun dan zat beta glucan dari gandum.

\section{Simpulan}

1. Pemberian bubur gandum dan minyak zaitun baik secara kombinasi maupun tunggal dapat menurunkan kadar kolesterol total dan LDL serum tikus.

2. Pemberian minyak zaitun lebih baik bila dibandingkan dengan pemberian bubur gandum terhadap penurunan kadar kolesterol total, tetapi tidak lebih baik dalam penurunan kadar kolesterol LDL serum tikus.

3. Pemberian kombinasi bubur gandum dan minyak zaitun lebih baik di dalam menurunkan kadar kolesterol total dan LDL serum tikus bila dibandingkan dengan pemberian bubur gandum.

4. Perbandingan antara pemberian kombinasi minyak zaitun dan bubur gandum dengan pemberian minyak zaitun saja tidak menunjukkan perbedaan yang bermakna dalam hal menurunkan kadar kolesterol total dan LDL serum tikus. 


\section{Research Article}

\section{Daftar Pustaka}

1. NCEP. ATP III Guidelines At-A-Glance. 2001 May.

2. Longo DL, Kasper DL, Fauci AS. Harrison's principles of internal medicine 18th edition United States of America: McGraw-Hill Companies; 2012.

3. Federation WH. http://www.world-heart-federation.org/. [Online].; 2011 [cited 20 May 2011]. Available from: HYPERLINK "http://www.world-heart-federation.org/press/fact-sheets/cardiovascular-disease-riskfactors/quick-facts-on-cholesterollipids/"

4. Harvard. http://www.hsph.harvard.edu/. [Online].; 2012 [cited 28 May 2013]. Available from: HYPERLINK "http://www.hsph.harvard.edu/obesity-prevention-source/obesity-causes/physical-activity-and-obesity/"

5. Perwitasari AS. Kontan.co.id All rights reserved. [Online].; 2012 [cited 2012 October 5. Available from: HYPERLINK "http://nasional.kontan.co.id/news/jumlah-warga-kelas-menengah-indonesia-meningkat"

6. Deaton A. http://www.nber.org/. [Online].; 2003 [cited 2003. Available from: HYPERLINK "http://www.nber.org/reporter/spring03/health.html" http://www.nber.org/reporter/spring03/health.html .

7. Dairy Council of California. Dairy Council of California. [Online].; 2013 [cited 2013. Available from: HYPERLINK "http://www.healthyeating.org/" http://www.healthyeating.org/ .

8. Gounelle,Fontan, Demarne.Olive oil and blood cholesterol levels. The American Journal of Clinical Nutrition. $1962 ;:$ p. 119-23.

9. Guyton AC, Hall JE. Textbook of medical physiology Twelfth Edition United States of America: Saunders Elsevier; 2011.

10. Tripoli E, Giammanco M, Tabacchi G, Majo DD, Giammanco S, Guardia ML. The phenolic compounds of olive oil: structure, biological activity. Cambridge Journal. 2005;: p. 98-112.

11. Visioli F, Galli C. The effect of minor constituent of olive oil on cardiovascular disease: new findings. Nutr Rev 1998; 56:142-7.

12. Pedersen, A., M. W. Baumstark, P. Marckmann, H. Gylling, and B. Sandström. An olive oil-rich diet results in higher concentrations of LDL cholesterol and a higher number of LDL subfraction particles than rapeseed oil and sunflower oil diets. J. Lipid Res. 2000. 41:1901-11. 